\title{
Analisis Kebijakan Ketahanan Pangan di Kabupaten Bantul
}

Ica Naisyah Tul Aisyahi ${ }^{1}$

Depertament of Government Affairs and Administration, Jusuf kalla School of Government, Universitas Muhammadiyah Yogyakarta. icaaisyiah1999@gmail.com

\section{Eko Priyo Purnomon ${ }^{\prime}$}

Depertament of Government Affairs and Administration, Jusuf kalla School of Government, Universitas Muhammadiyah Yogyakarta eko@umy.ac.id

\section{Aulia Nur Kasiwi ${ }^{3}$}

Depertament of Government Affairs and Administration, Jusuf kalla School of Government, Universitas Muhammadiyah Yogyakarta aulianurkasiwi@gmail.com
E-ISSN (2721-0642)

Recieved:

May 92020

Revised:

August 142020

Accepted:

August 192020

Doi Number

10.37950/ijd.v2i2.40

\section{Abstract}

The Regional Government of Yogyakrata City has provided food security in the city of Yogyakarta especially, in Bantul Region which has its own food security service. With the existence of the Department of Food Security and the availability of food security, it can help the local community to understand the needs and availability of food in the Bantul area. Then the Bantul area established a resilience policy in the Bantul area. if food security meets the applicable requirements, the community will not be malnourished. The impact if there is a lack of food, namely, malnutrition, poverty, a weak economy and so on. This study uses qualitative methods which can describe and explain about this research. The results of research on food security or food availability in the Bantul area by using existing policies.

Keywords: food security, policy, nutrition.

\section{Abstrak}

Pemerintah Daerah kota Yogyakrata telah menyediakan ketahanan pangan yang ada di Kota Yogyakarta khusunya, di Daerah bantul yang memiliki Dinas ketahanan pangan tersendiri. Dengan adanya Dinas Ketahanan pangan dan tersedianya ketahanan pangan tersebut maka dapat membantu masyarakat local untuk memenehui kebutuhan dan ketersedian pangan yang ada di daerah Bantul. Kemudian daerah bantul menetapkan kebijakan ketahanan di daerah bantul. jika ketahanan pangan memenuhi syarat yang berlaku maka masyarakat tidak akan kekurangan gizi. Dampak jika terjadi kekurangan 
pangan yaitu, kekurangan gizi, kemiskinan, perekonomian lemah dan sebagainya. Penelitian ini menggunakan metode kualitatif dimana dapat menggambarkan dan mejeleaskan tentang penelitian ini. Hasil penelitian ketahanan pangan atau ketersedian pangan di daerah Bantul dengan menggunakan kebikan yang ada.

Katakunci: ketahanan pangan, kebijakan, gizi

\section{Pendahuluan}

Di daerah Yogyakarta terkenal dengan angka kemiskinan yang melonjak tinggi dari tahun ketahun. Semenjak tahun 2013 sampai saat ini, masih belum bisa di atasi. padahal kota Yogyakarta di kenal dengan kota wisata dan kota pelajar dimana banyak orang-orang yang berbondong-bondong ke Yogyakarta. Akan tetapi kota Yogyakarta masih saja terbilang kota termiskin. Namun angka kebahagiaan paling tinggi. Pemasukan dalam pemerintah juga semakin banyak karena banyaknya wisata asing yang masuk dalam kota Yogyakarta. Maka dari itu, Dengan pertimbangan pentingnya ketahanan pangan dan kota Yogyakarta yang terbilang miskin tersebut pemerintah sangat mengupayakan agar dapat meningkatkan ketersedianan ketahanan pangan yang berasal atau bersumber dari tingginya produksi dalam negeri. Menurut (Rachman, Agustian, \& Wahyudi, 2018) dalam (Suryana, 2013), ketidakstabilan produksi pangan serta kecendrungan harga bahan pokok atau bahan dasar dapat menyebabkan meningkatnya inflasi harga yang akan mengurasharga dan pendapatan masyarakat miskin yang akhirnya akan menambah angka kemiskinan atau jumlah kemiskinan di daearh tersebut ataupun di seluruh dunia. Ini juga sangat di pertimbangkan karena Indonesia saat ini jumlah penduduk semakin besar dan tingkat populasi nya juga semakin besar sama dengan di Yogyakarta semakin banyak penduduk yang masuk. Khusunya di daerah Bantul banyak pemasukan dan pendatang. Maka dengan itu peneliti tertarik meneliti "studi kasus tentang seberapa kuat ketahanan pangan di Yogyakarta khusunya daerah Bantul".

Kurangnya keterediaan pangan terjadi karena masih kurangnya bahan pokok, meningkatnya angka pengangguran, mahalnya produk pangan, rendahnya ekonomi masyarakat dan sebagainya. bahan dasar pokok yang mencukupi kehidupan di seluruh dunia. Jika ketersedian pangan berkurang maka akan meresahkan kehidupan masyarakat di seluruh dunia. ketahanan pangan juga merupakan ketersedian pangan dan kemampuan seseoarang untuk mengakses rumah tangga. Ukuran kelentingan hidup terhadap gangguan pada masa depan dapat menyebabkan ketiadaan suplai pangan akibatnya dapat menyebabkan kekeringan, peperanganm gangguan perlengkapan, kelangkaan bahan, tidak stabilnya ekonomi dan senagainya. Menurut (World health Organization), komponen utama dalam ketahanan pangan ada tiga yaitu, ketersedian pangan, akses pangan dan pemanfaatan pangan (bahan pokok). Pangan adalah keperluan atau kebutuhan pokok dalam rumah tangga yang utama bagi manusia harus di penuhi setiap saat. Dalam pasal 27 UUD 1945 dalam deklarasi roma 1996, salah satu hak asasi manusia yaitu hak untuk memperoleh pangan. Ini terjadi karena pangan merupakan kebutuhan dasar yang mempunyai peran sangat penting dalam kehidupan suatu bangsa. Jika Ketersedian pangan makin kecil atau 
sedikit maka dapat menyababkan tidak stabilnya pertumbuhan ekonomi. Menurut (Setiawan Wisnu Asrul, 2015) dalam (Boediono, 2009: 1) Pertumbuhan ekonomi adalah sebuah proses, diaman dalam hal ini bukan suatau penjelasan atau gambaran ekonomi untuk suatau saat. Pertumbuhan ekonomi yang merupakan perubahan dalam jangka panjang secara bertahap dalam produksi barang dan jasa.

Di Indonesia pangan sering diidentifikasi dengan beras. Karena jenis pangan ini merupakan hal pokok atau paling utama. Jadi jika harga beras naik maka akan mengakibatkan seluruh bangsa tersebut dapat mengalami kekurangan bahan pangan dan mangalami gangguan ketahanan pangan. Misalnya pada tahun 1997/1998 terjadi krisis ekonomi yang mengakibatkan akan terjadinya kerawanan sosial yang dapat membahayakan kestabilan ekonomi dan tingkat nasioanal. Dalam masyarakat beras merupakan pokok paling penting dalam industry ekonomi karena membawa pengaruh besar dalam pertumbuhan ekonomi. Sumber utama dalam pemenuhan gizi yang dapat d cukupi yang bisa mencakup kalori, lemak, vitamin dan proteinjika ketahanan pangan yang ada di Indoensia banyak tersedia maka rakyat indoensia tidak akan mengalami kekurangan pangan dan ketahanan pangannya. Menurut (Ariani \& Ashari, 2016) dalam (Rahardjo, 1993), untuk usaha dalam pemenuhan kebutuhan pangan, lembaga pemerintahan telah mengupayakan agar kebutuhan pangan bisa terpenuhi dan hal ini dapat diwujudkan dalam mencapai swasembada pangan yaitu beras yang di targetkan.

Masalah yang sering terjadi adalah masalah pangan dan gizi dimana hal ini saling berkaitan. Hal ini di sebabkan, dari berbagai faktor, salah satunya faktor konsumsi pangan. Menurut Park (2005) et al., faktor yang dapat mempngaruhi konsumsi pangan adalah faktor sosial budaya, gaya hidup, demografi dan gaya hidup. Berkaitan dengan hal tersebut, terdapat penilaian terhadap pola konsumsi pangan pada masyarakat yang dapat di jadikan upaya untuk menjelaskan dan menggamabrkan keadaan pangan dan gizi di masyarakat. Menurut Leyna (2010) et al., pola konsumsi pangan pada masyarakat saling berhubungan sugnifikan dengan kondisi dimana ketahanan pangan masyarakat. Jika kondisi makanan atau ketersedian pangan baik, maka pola konsumsi pangan akan lebih berkualitas.

\section{Kerangka Teori}

Sesuatu yang berasal dari sumber alam hayati dan air, baik yang dapat diolah secara baik maupun tidak di olah dengan baik, yang khususnya untuk makanan dan minuman untuk konsumsi manusia termasuk dalam bahan tambahan pangan, bahan baku pangan, serta bahan yang lain yang dapat digunakan dalam penyiapan, pengolahan dan minuman untuk konsumsi manusia yang termasuk untuk tambahan pembuatan makan dan minumanyang ini semua merupakan pangan. Menurut Bappenas (2011), Dimana pangan merupakan bahan yang bersumber dari karbohidrat yang sering di konsumsi secara teratur untuk makanan utama, dan menjadi bahan sampingan, sebagai sarapan untuk makanan pembuka atau penutup. Dalam hal ini, konsumsi pangan yang merupakan kebutuhan pokok untuk setiap individu yang wajib untuk dapat di penuhi. Menurut peraturan pemerintah No. 68 tahun 2002 ketahan pangan merupakan dimana kondisi masyarakt di daerah tersebut dapat terpenuhi dalam bidang pangan bagi rumah tangga yang terlihat tersedianya pangan yang sangat cukup untuk jumlah yang banyak maupun, kualitas, aman, merata dan dapat di jangkau oleh semua masyarakat. Dengan tercukupinya pangan secara nasioanl nasioanl 
bukan berarti dapat menjamin bahwa semua masyarkat di Indonesia atau orang (keluarga) dapat memperoleh makan yang dibutuhkan tersebut.

Jika jumlah anggota rumah tangga yakni berjumlah 3-4 orang maka termasuk golongan yang ideal, dan jika dalam rumah tangga tersebut suami dan istri sama-sama bekerja maka akan mengurangi pengangguran dan menambah pendapatan dalam rumah tangga sehingga dengan ini dapat mengatasi ketersediaan pangan. pengeluaran, pangan, pendapatan rumah tangga. (Khomsan, A. (2013) et al.; Jayarni, D. E. (2008), et al.; Sinaga, R. J. R. (2018), et al.. Menurut Heny Herawati (2008), ada lima pendekatan yang digunakan dalam penentuan umur dalam produk simpan pangan yaitu, literature value, distribution turn over, distribution abuse test, complain konsumen, dan ASLT. Menurut ( Suryana, Achmad (2008) \& Purwantini, T. B., (2014), ketahanan pangan nasional adalah pembentukan utama dalam sumberdaya mansuia dan generasi berkualitas, sehingga dapat membangun bangsa di era globalisasi. Dalam rumah tangga umur kepala rumah tangga sangat berpengaruh terhadap ketahanan pangan. Seperti status perkawinan, jumlah anggota, pendapatan rumah tangga, ini sangat berpengaruh terjadap ketahanan pangan. (Heni Susilowati; 2014).

Masalah gizi juga sangat berkaitan dengan masalah pangan, ini sangat berkaitan dengan keterbatasan pangan dan gizi. Adapun cara untuk mengatasi keterbatasan pangan dan gizi terkait dengan tolak ukur ketahanan pangan dan gizi yaitu produksi dan ketersedian pangan, distribusi dan akses pangan, konsumsi dan keamanan pangan serta status gizi pada masyarakat. Ketahanan pangan dan gizi sangatlah penting untuk satu pilar ketahanan nasioanal serta wilayah, jika perspektif kedepan memungkinkan perubahan pendekatan paradigm dalam membangun pangan dan ketahanan pangan/ food security. Sehingga dengan ini, akan lebih komprehensif. Penyediaan pangan pokok dalam rumah tangga terhadap petani yang dapat di analisis dengan terbatas pada ketersedian pangan pokok dari beras. Dimana beras ialah makanan bahan pokok untuk sebagian besar penduduk Indonesia yang memiliki kontribusi terhadap konsumsi kalori yaitu 55\%. Konsumsi protein 44\%. Di pulau jawa yang merupakan sentra produksi nasioanal, dari tahun $1985-2005$ yaitu 55562\% yaitu produksi padi nasioanl yang dapat dihasilkan di pulau jawa dan sekitarnya (Irawan dan Sutrisna, 2011). Ketersedian pangan dengan rata-rata menggunakan beras (bahan pokok) dalam rumah tangga petani termasuk dalam kategori rendah yang diamana bahan pangan pokok dalam rumah tangga yaitu beras. Bahan pokok yang sering di konsumsi adalah umbi-umbian seperti singkong (Kusumawati, T. D., (2013) et al.)

Jika alih fungsi lahan dapat di kendalikan dengan baik maka tidak adanya ancaman dalam ketahanan pangan. Ketahanan pangan penduduk dapat terjaga jika ketahanan pangan penduduk dapat terpenuhi dengan baik. Maka dengan adanya tambahan luas lahan sawah, peningkatan produktiviras lahan, dan mengurangai pangan penduduk. Prasada I. M. Y., (2018), et al., Ada empat faktor dalam pembentukan ketersedian pangan antara lain; faktor sosial ekonomi, kesehatan, fsisik alam, ini dapat mempengaruhi kerawanan yang dapat membntuk lima kelompok yaitu; sosial ekonomi, infrastruktur, iklim, lingkungan, dan produktivitas lahan. (Hapsari, N. I. \& Rudiarto, I. : 2017).

Dalam pengembanganagan agroindustry mengupayakan berkembangnya agroindustry dalam rumah tangga yang kemudian dapat meningkatkan kesejahteraan rumah tangga sehingga dapat mengatasi masalah ketahanan pangan. (Dwidjono $\mathrm{H}$. Darwanto; 2005). Kemudian dengan adanya program bantuan non tunai (BPNT) 
sehingga dapat mengatasi ketahanan pangan dan membuat masyarakatr sejahtera. Program ini dapat memenuhi tiga indicator yaitu jumalh, kualitas dan harga (Ahda S. Nisa; 2019). Pendapatan dalam anggota rumah tangga dapat mempengaruhi konsumsi dan ketahanan pangan seperti energy dan konsumsi protein anggota dalam rumah tangga (Kusumawati, T. D., (2013) et al.,)

UU RI NO. 18 tahun 2012 tentang pangan di jelaskan bahwa pangan ialah kebutuhan dasar manusia yang paling utama yang merupakan pemenuhan utama dalam masyarakat, ini juga merupakan hak asasi manusia yang dapat diterima. Dalam UUUD Negara Republik Indonesia tahun 1945 yang merupakan komponen dasar dalam mewujudkan sumber daya manusia yang berkuaitas. Akan tetapiaturan/ UU tersebut di ganti dan yerdapat dalam Bab 1, pasal 1, yaitu pangan adalah sesuatu yang beraslah dari sumber alami/ hayati, sperti priduk pertanian, perkebenan, kehutanan, perikanan, peternakan, perairan, air baik yang di olah maupuntodak diolah. Hak Negara dalam suatau bangsa dapat menentukan sistem pangan yang sesuai dengan potensi sumber daya yang ada (Undang-Undang Republik Indonesia, N0 18 tahun 2012 tentang pangan).

Kegiatan yang dapat menghasilkan, mengelolah, menyiapkan, membuat, mengawetkan, mengemas, mengemas kembali, ini merupakan produksi pangan. Kondisi dimana tersedia pangan akan hasil produksi dalam negeri dan cadangan pangan nasioanal yang dimpor yang dimana sumber tersebut tidak memenuhi kebutuhan sumber. Adapun konsumsi pangan local di masyarakat setempat yang potensi dserta kearifan local (Undang-Undang Republik Indonesia, N0 18 tahun 2012 tentang pangan).

\section{Metode Penelitian}

Dalam penelitian kali ini, peneliti menggunakan metode kulitati deskriptiff, dengan cara mendiskripsikan dan mengetahui cara menangani masalah ketahanan pangan yang cukup relative. Dengan menggunakan metode ini juga peneliti dapat menggali tentang cara-cara pemerintah dalam menanggulangi masalah ketahan pangan dan kemiskinan tersebut. Menurut (Wulandari \& Purnomo, 2019) jenis penelitian deskriptif dengan menggunakan pendekatan kualitatif yang merupakan pendekatan untuk memberikan, gambaran, serta penjelasan tentang masalah yang di teliti sehingga jelas tentang masalah yang diteliti.

\section{Hasil dan Diskusi}

A. Gambaran Umum Wilayah

Daerah Bantul khususnya kabupaten Bantul merupakan daerah istimewa yogyakarta, dimana propinsi ini, terdapat empat kabupaten salah satunya kabupaten Bantul. dan memiliki satu kota. Daerah tersebut memiliki luas yang sangat besar yaitu 506,85 km2 kemudian terdapat 17 kecamatan, 75 desa serta 933 pedukuhan. Secara

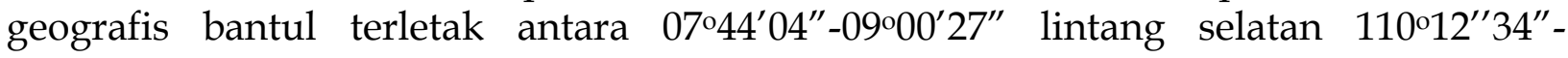
110'31'08" bujur timur. Di wilayah ini, dilewati tiga sungai antara lain adalah Sungai ptogo, Sungai Opak, dan sungai Oya. Daerah ini juga, memiliki batas-batas wilayah antara lain adalah wilayah bagian sebelah timur Yogyakarta ada daerah kabupaten sleman, di daerah bagian barat ada Samudera Hindia, di daerah bagian selatan ada daerah kulon progo dan yang terkahir di daerah bagian utara ada darah Gunung Kidul. 
Kabupaten bantul terdapat wilayah yang memiliki ketinggian di atas permukaan laut, yang banyak dan bervariatif di antara 25-2500 M DPL. Dan daerah ini memiliki banyak kecamatan yaitu 17 kecamatan. Di Kecamatan Srandakan dan daerah sanden terdapat tempat yang sangat rendah yaitu antara 0-25 M DPL. Hal ini terjadi karena daerah tersebut berada di wilayah pesisir pantai selatan dan daearh kecamatan tersebut memiliki ketinggian hingga 50-500 M DPL dengan topografi yang pegunungannya yang sangat relative rendah (Basuki, A.T. \& Krismawan, H.; 2016)

\section{Tabel 1}

Luas Wilayah dan Banyaknya Desa Menurut Kecamatan di Kabupaten Bantul

\begin{tabular}{|c|l|c|c|c|}
\hline No. & \multicolumn{1}{|c|}{ Kecamatan } & $\begin{array}{c}\text { Luas Wilayah } \\
(\mathbf{H a})\end{array}$ & $\begin{array}{c}\text { Persentase Luas } \\
(\%)\end{array}$ & $\begin{array}{c}\text { Banyaknya } \\
\text { Desa }\end{array}$ \\
\hline 1 & Srandakan & 1.832 & 3,61 & 2 \\
\hline 2 & Sanden & 2.316 & 4,57 & 4 \\
\hline 3 & Kretek & 2.677 & 5,28 & 5 \\
\hline 4 & Pundong & 2.368 & 4,67 & 3 \\
\hline 5 & Bambanglipuro & 2.270 & 4,48 & 3 \\
\hline 6 & Pandak & 2.430 & 4,79 & 4 \\
\hline 7 & Bantul & 2.195 & 4,83 & 4 \\
\hline 8 & Jetis & 2.447 & 10,75 & 8 \\
\hline 9 & Imogiri & 5.449 & 11,02 & 6 \\
\hline 10 & Dlingo & 5.587 & 4,53 & 5 \\
\hline 11 & Peret & 2.297 & 6,42 & 3 \\
\hline 12 & Piyungan & 3.254 & 5,62 & 8 \\
\hline 13 & Banguntapan & 2.848 & 5,36 & 4 \\
\hline 14 & Sewon & 2.716 & 6,39 & 3 \\
\hline 15 & Kasihan & 3.238 & 6,78 & 4 \\
\hline 16 & Pajangan & 3.325 & 100,00 & 75 \\
\hline 17 & Sedayu & 3.436 & & \\
\hline & Jumlah & 50.685 & & 4 \\
\hline
\end{tabular}

Sumber : Bantul dalam Angka, 2014

Tabel 2

Tinggi Wilayah Diatas Permukaan Laut (DPL) Menurut Kecamatan di Kabupaten Bantul, 2013

\begin{tabular}{|c|l|r|}
\hline No. & \multicolumn{1}{|c|}{ Kecamatan } & Tinggi DPL ( m) \\
\hline 1 & Srandakan & $0-25$ \\
\hline 2 & Sanden & $0-25$ \\
\hline 3 & Kretek & $0-500$ \\
\hline 4 & Pundong & $7-500$ \\
\hline 5 & Bambanglipuro & $7-100$ \\
\hline 6 & Pandak & $7-100$ \\
\hline 7 & Bantul & $25-100$ \\
\hline 8 & Jetis & $25-500$ \\
\hline 9 & Imogiri & $7-500$ \\
\hline 10 & Dlingo & $25-500$ \\
\hline 11 & Pleret & $25-500$ \\
\hline 12 & Piyungan & $25-500$ \\
\hline 13 & Banguntapan & $25-500$ \\
\hline 14 & Sewon & $25-100$ \\
\hline
\end{tabular}


Volume 2, Issue 2, August 2020

http://hk-publishing.id/ijd-demos

\begin{tabular}{|c|l|c|}
\hline No. & \multicolumn{1}{|c|}{ Kecamatan } & Tinggi DPL (m) \\
\hline 15 & Kasihan & $25-500$ \\
\hline 16 & Pajangan & $7-500$ \\
\hline 17 & Sedayu & $25-500$ \\
\hline
\end{tabular}

Sumber : Bantul dalam Angka, 2014

Tabel 3.3.

Luas Daerah Menurut Ketinggian dari Permukaan Laut di Bantul $\left(\mathrm{km}^{2}\right), 2013$

\begin{tabular}{|c|c|c|c|c|c|c|}
\hline \multirow{2}{*}{ No. } & \multirow{2}{*}{ Kecamatan } & \multicolumn{4}{|c|}{ Ketinggian (m) } & \multirow{2}{*}{ Jumlah } \\
\hline & & $<100$ & $100-499$ & $500-999$ & $>1.000$ & \\
\hline 1 & Srandakan & 1.834 & $=$ & $\cdot$ & $\cdot$ & 1.834 \\
\hline 2 & Sanden & 2.327 & - & - & - & 2.327 \\
\hline 3 & Kretek & 2.449 & 101 & - & - & 2.550 \\
\hline 4 & Pundong & 2.177 & 199 & - & - & 2.376 \\
\hline 5 & Bambanglipuro & 2.282 & $\cdot$ & - & - & 2.282 \\
\hline 6 & Pandak & 2.429 & - & - & - & 2.429 \\
\hline 7 & Bantul & 2.199 & - & - & - & 2.199 \\
\hline 8 & Jetis & 2.549 & 11 & - & - & 2.560 \\
\hline 9 & Imogiri & 3.509 & 2.272 & - & - & 5.781 \\
\hline 10 & Dlingo & 815 & 4.819 & - & - & 5.634 \\
\hline 11 & Pleret & 1.783 & 345 & - & - & 2.128 \\
\hline 12 & Piyungan & 1.965 & 1.347 & - & - & 3.312 \\
\hline 13 & Banguntapan & 2.154 & 475 & $\cdot$ & - & 2.629 \\
\hline 14 & Sewon & 2.676 & $\cdot$ & - & - & 2.676 \\
\hline 15 & Kasihan & 2.608 & 630 & - & - & 3.238 \\
\hline 16 & Pajangan & 2.867 & 452 & - & - & 3.319 \\
\hline 17 & Sedayu & 3.262 & 149 & - & $\cdot$ & 3.411 \\
\hline
\end{tabular}

Sumber : Bantul dalam Angka, 2014

\section{B. Kebijakan ketahanan pangan.}

Di dalam Undang-undang nomor 41 tahun 2009 menjelaskan perlindungan lahan pertanian pangan yang berkelanjutan. Pangan local merupakan pangan yang di produksi oleh satu wilayah/daerah yang bertujuan untuk ekonomi atau konsumsi. Bahan pangan yang berbentuk primer maupun sekunder. Menurut Badan ketahanan pangan kementrian pertanian (BKPKP), jenis pangan local yang cukup banyak akan di seberkan keseluruh daerah. Adapun beberapa jenis pangan local yang dapat dikelola yaitu yang mempunyai nilai ekonomis yang tinggi yang meliputi, jagung, daging, beras, telur dan ikan. Akan tetapi, ada potensi pangan yang belum di manfatkan oleh masyarakat yaitu; sagu, umbi-umbian dan sebagainya (Wastutiningsih, S. P. \& Untari D. W.; 2011)

Rancangan Undang-undang tentang pangan, Bab XI yaitu penelitian dan pengembangan masyarakat. Dimana pada bab ini dan pada pasal ini menjelaskan tentang pemerintah pusat dapat melindungi ketahanan pangan, mendaftarkan ketahanan pangan yang unggul agar ketahanan pangan tersebut dapat di ketahui oleh masyarakat banyak, kebijkan ini berlaku dalam pemerintahan pusat/provinsi. Sedangkan ada kebijakan yang harus di sosialisasikan, baik dari kalangan orang besar sampai ke kalangan anak anak, dan baik dari tingkat provinsi sampai kabupaten. Kebijakan tentang pangan ini harus di sosialisasikan agar masyarakat dan anak-anak bisa mengetahi tentang pentingnya pangan/ketahanan pangan. Dalam bab XI, pasal 
117 berisi tentang, pengembangan dan penelitian yang yang dilakukan dalam pengambangan pangan. Sehinga untuk memajukan pengetahuan tentang teknolgi, pangan yang dapat dijadikan dasar dalam sebuah kebujakan pangan, agar dapat meningkatkan kedaulatan pangan, kemandirian pangan dan ketahanan pangan tersebut (Undang-Undang Republik Indonesia, N0 18 tahun 2012 tentang pangan)

\section{Ketahanan pangan yang ada di bantul}

Di daerah Yogyakarta memiliki ketersedian pangan untuk masyarakat yang ada di daerah tersebut khusunya, daerah Bantul. Di daerah bantul memiliki ketersedian pangan lokal untuk mengatasi masalah kekurangn pangan. Ketersedian pangan yang ada di bantul seperti ; beras, gandum, ubi kayu, ubi jalar, pisang dan jagung. Masyarakat bantul dan dinas ketahanan bantul menyediakan sarana untuk kebutuhan pangan tersebut, untuk ketahanan hidup masyarakat bantul. Sehingga masyarakat bantul tidak akan kesusahan pangan dan memiliki ketersedian pangan yang melimpah. Bantul juga memiliki kebijkan pemerintah daerah bantul di bidang pertanian dan pangan. Dinas ketahanan pangan juga memberikan bantuan kepada masyarakat berupa alat untuk ketahanan pangan. Untuk itu, bantul sudah menyediakan ketersedian pangan untuk memenuhi kebutuhan hidup masyarakatnya. Menurut (Wastutiningsih, S. P. \& Untari D. W.; 2011) ada beberapa cara untuk mengatasi ketersedian pangan di daerah pemerintahan Bantul dalam bidang pertanian antara lain:

a) Adanya perlindungan petani di areal pertanian yaitu dengan melarang pembangunan Mall di daerah tersebut, dan adanya petani yang mempertahankan areal swahnya, kemudian PBBnya di support APBD.

b) Meningkatkan peran penyuluhan pertanian

c) Meningkatkan diversifikasi dalam usaha tani, seperti kambing, pemeliharaan lembu, ikan, ayam serta penjualan di pasar tradisional.

d) Meningkatkan kemitraan antara pihak satu dengan yang lain dengan menuntungkan petani.

Adanya edaran surat dari Bupatai Bantul pada tanggal 19 April 2010 No $511 / 1400$ tentang

a) Dapat menghargai serta memberikan peluang besar terhadap pasar untuk hasil jerih payah petani di daerah tersebut.

b) Dapat mengahadapi persaingan pasar setelah adanya perdagangan bebas ASEAN-Cina ( ASEAN-China Free Trade Agreement.

c) Dapat meningkatkan pendapatan petani Bantul.

Adanya surat edaran dari Bupati tentang pertanian ini, dapat menghimbau untuk seluruh pejabat di SKPD (Satuan Kerja Pangkat Daerah). kabupaten bantul, untuk memprioritaskan pengguna bahan pangan hasil daerah tersebut, dan dapat meminimalisirkan penggubaan bahan pangan impor seperti gandum, buah-buahan dan lain-lain. Dalam berbagai kegiatan yang di lakukan dalam pemerintahan kabupaten Bantul yaitu BKP3 menjelaskan yaitu; menginformasikan tentang keutamaan pangan local oleh Bupati Bantul, pejabat yang hadir, wakil Mentri pertanian, kepala pusat penyuluhan pertanian, kepala badan ketahanan penyuluhan pertanian/BKPP di daerah DIY. Di kegiatan ini, pada tahun 2011 yaitu tentang adanya deklator untuk komponen dalam masyarakat bantul, di Daerah Istimewa Yogyakarta merupakan bagian dari bangsa Indonesia yang mengatakan bahwa sangat mendukung adanya pengutamaan penggunaan bahan lokalyang pemerintahnya sangat bertekad untuk menjadikan daerah Bantul sebagai daerah yang Projotamansari, sejahtera, Demokratis dan selalu 
semangat dalam hal apapun, dan untuk mendorong masyarakat yang dapat mengembangkan potensi yang ada di daerah tersebut khusunya potensi pangan local untuk terwujudnya ketahanan pangan nasioanal, agar terciptanya bangsa yang mandiri yang dapat menghidupi masyarakatnya sendiri dari olahan rakaytnya sendiri.

\section{Analisa.}

Menurut peraturan pemerintah No. 68 tahun 2002 ketahan pangan merupakan dimana kondisi masyarakt di daerah tersebut dapat terpenuhi dalam bidang pangan bagi rumah tangga yang terlihat ketersedian panganya yang sangat cukup untuk jumlah yang banyak serta, kualitas, aman, merata dan dapat di jangkau oleh semua masyarakat. Maka dengan adanya kebijkan pemerintahan bantul untuk ketahanan pangan di masyarakat bantul, masyarakat tidak perlu takut jika ketahanan pangannya habis. Karena dinas ketahanan pangan telah meneyediakan beberapa kebijakan tentang ketahanan pangan. Akan tetapi implementasinya, walaupun kebijakan pemerintah tersebut berjalan dengan baik. Namun ada beberapa kebijakan yang tidak berjalan dengan sewajarnya. Ketahanan pangan memiliki peran yang sangat penting dalam masyarakat. Dengan adanya ketahanan pangan maka akan menjamin hak atas ketersedian pangan, dapat menjadi pilar ketahanan pangan masyarakat, dan membentuk SDM (Sumber daya manusia) yang berkualitas. Semakin bertambahnya penduduk dan semakin luasnya wilayah di bantul maka akan semakin bertambah juga ketersedian pangan yang ada di bantul. Namun jika semakin luas wilayah yang ada di bantul maka ketersedian ketahanan pangan akan banyak.

Ada gejala umum yang sering terjadi pada pangan yaitu, ketahanan pangan, keamanan pangan, kerawanan pangan, kemiskinan dan gizi buruk. Di beberapa daerah masih rentan dengan hal tersebut. Karena ketidak mampuan rumah tangga untuk memenuhi pangan. Masalah gizi juga sangat berkaitan dengan masalah pangan, ini sangat berkaitan dengan keterbatasan pangan dan gizi. Adapun cara untuk mengatasi keterbatasan pangan dan gizi terkait dengan tolak ukur ketahanan pangan dan gizi yaitu produksi dan ketersedian pangan, distribusi dan akses pangan, konsumsi dan keamanan pangan serta status gizi pada masyarakat. Sehingga dengan ini, status gizi juga harus di perhatikan agar tercapainya masyarakat yang sejahtera dan memiliki ketersedian pangan yang melimpah. akan lebih komprehensif lagi jika Penyediaan pangan pokok dalam rumah tangga pada petani yang terbatas memberikan bantuan seperti beras, jagung, ubi-ubian dan lain-lain,. terhadap petani agar dapat mengelolah hasil pertanian yang kemudian akan menghasilkan ketersedian pangan tersebut. sehingga pada ketersedian pangan pokok dari beras akan tersedia dan akan terciptanya masyarakat yang sejahtera.

Di dalam Undang-Undang No. 7 tahun 1996 tentang pangan. Yaitu menjelaskan pemerintah bertanggung jawab dalam mewujudkan ketahanan pangan dengan prinsip, integrative, partisipatif, dan pemberdayaan. Maka dengan itu, ketahanan pangan di suatau daerah harus di jaga agar tidak terjadinya ancaman yang berbahaya dalam ketahanan nasioanal. Satu pilar ketahan atau ketersediaan pangan dalam mewujudkan prioritas dalam ,merencanakan implememntasi dalam pembangunan di suatau daerah tersebut di sebut ketahanan pangan. Namun, peran pemerintah pusat di daearah/kabupaten masih sangat sentral di karenakan ketahanan pangan tersebut harus dimulai dari masing-masing rumah tangga di daerah itu sendiri. Maka dengan ini, dapat mengatasi penanganan masalah dalam satu instansi pemerintahan tersebut. Akan tetapi, dalam hal ini koordinasi harus sangat efektif dari berbagai lembaga seperti 
dari lembaga pemerintahan, swasta dan masyarakat sehingga Akan tetap, berjalan dengan baik.

Dengan kebijakan yang ada yaitu Adanya perlindungan petani di areal pertanian yaitu dengan melarang pembangunan Mall di daerah tersebut. Akan tetapi di daerah Bantul sudah banyak bangunan baru di daerah persawahan dan banyaknya bangunan perumhan mewah. Jadi, kebijakan yang ada belum terlaksanakan dengan baik dan kekuatan hukum serta penegakkan hukum yang kurang kuat.

\section{Kesimpulan.}

Ketahanan pangan memiliki peran yang sangat penting dalam masyarakat. Dengan adanya ketahanan pangan maka akan menjamin hak atas ketersedian pangan, menjadi pilar ketahanan pangan masyarakat, dan dapat membentuk SDM yang berkualitas. Semakin bertambahnya penduduk dan semakin luasnya wilayah di bantul maka akan semakin bertambah juga ketersedian pangan yang ada di bantul. Namun jika semakin luas wilayah yang ada di bantul maka bisa menyediakan ketahanan pangan dalam bnetuk yang banyak. status gizi juga harus di perhatikan agar tercapainya masyarakat yang sejahtera dan memiliki ketersedian pangan yang melimpah. sehingga pada ketersedian pangan pokok dari beras akan tersedia dan akan terciptanya masyarakat yang sejahtera.

\section{Tentang Penulis}

Ica Naisyah Tul Aisyahi adalah mahasiswa Depertament of Government Affairs and Administration, Jusuf kalla School of Government, Universitas Muhammadiyah Yogyakarta.

Eko Priyo Purnomo merupakan dosen di Depertament of Government Affairs and Administration, Jusuf kalla School of Government, Universitas Muhammadiyah Yogyakarta

Aulia Nur Kasiwi merupakan dosen di Depertament of Government Affairs and Administration, Jusuf kalla School of Government, Universitas Muhammadiyah Yogyakarta

\section{Ucapan Terimakasih}

Terimakasih kepada dosen saya yang telah membimbing dalam menyelesaikan artikel ini, dan terimakasih kepada International Journal of Demos yang telah menerbitkan artikel ini.

\section{References}

Ariani, M. (2019). Arah, Kendala dan Pentingnya Diversifikasi Konsumsi Pangan di Indonesia.

Bappenas. 2011. Rencana Aksi Nasional Pangan dan Gizi 20112015. Badan Perencanaan Pembangunan Nasional. Jakarta.

Basuki, A. T., \& Krismawan, H. E. N. R. Y. (2016). Kajian Pangan Lokal Di Kabupaten Bantul Tahun 2016. Repository. um. ac. id. Diakses online pada tanggal, 20. 
Boediono. 2009. Teori Pertumbuhan Ekonomi. Edisi ketujuh.BPFE-Yogyakarta. Yogyakarta

Darwanto, D. H. (2005). Ketahanan pangan berbasis produksi dan kesejahteraan petani. Ilmu Pertanian, 12(2), 152-164.

Florence, A. G. (2017). Hubungan Pengetahuan Gizi dan Pola Konsumsi dengan Status Gizi Pada Mahasiswa TPB Sekolah Bisnis dan Manajemen Institut Teknologi Bandung (Doctoral dissertation, Fakultas Teknik Unpas).

Hapsari, N. I., \& Rudiarto, I. (2017). Faktor-Faktor yang Mempengaruhi Kerawanan dan Ketahanan Pangan dan Implikasi Kebijakannya di Kabupaten Rembang. Jurnal Wilayah dan Lingkungan, 5(2), 125-140.

Herawati, H. (2008). Penentuan umur simpan pada produk pangan. Jurnal Litbang Pertanian, 27(4), 124-130.

Irawan, Bambang, dan Sutrisna, Nana. 2011. Prospek Pengembangan Sorgum di Jawa Barat mendukung Diversifikasi Pangan. Forum Penelitian Agroekonomi. Vol. 29 (II): 100.

Jayarni, D. E., \& Sumarmi, S. (2018). Hubungan Ketahanan Pangan dan Karakteristik Keluarga dengan Status Gizi Balita Usia 2-5 Tahun (Studi di Wilayah Kerja Puskesmas Wonokusumo Kota Surabaya). Amerta Nutrition, 2(1), 44-51.

Khomsan, A., Riyadi, H., \& Marliyati, S. A. (2013). Ketahanan pangan dan gizi serta mekanisme bertahan pada masyarakat tradisional Suku Ciptagelar di Jawa Barat. Jurnal Ilmu Pertanian Indonesia, 18(3), 186-193.

Kusumawati, T. D., Marwanti, S., \& Ani, S. W. (2013). Analisis Ketersediaan Pangan Pokok dan Pola Konsumsi Pangan Rumah Tangga Petani di Kecamatan Nogosari Kabupaten Boyolali. Universitas Sebelas Maret. Surakarta.

Nisa, A. S. (2019). Analisis Program Bantuan Pangan Non Tunai (Bpnt) Guna Meningkatkan Kesejahteraan Masyarakat Dalam Perspektif Ekonomi Islam (Studi Kasus di Desa Merak Batin Kecamatan Natar Kabupaten Lampung Selatan) (Doctoral dissertation, UIN Raden Intan Lampung).

Prasada, I. M. Y., \& Rosa, T. A. (2018). Dampak Alih Fungsi Lahan Sawah Terhadap Ketahanan Pangan Di Daerah Istimewa Yogyakarta. Jurnal Sosial Ekonomi Pertanian, 14(3), 210-224.

Presiden, R. I. (2012). Undang-undang Republik Indonesia Nomor 18 tahun 2012 tentang Pangan. Jakarta: Kementerian Hukum dan HAM RI.

Purwantini, T. B. (2016). Pendekatan rawan pangan dan gizi: besaran, karakteristik, dan penyebabnya.

Rachman, B., Agustian, A., \& Pangan, B. K. (2019). Efektivitas dan perspektif pelaksanaan program beras sejahtera (Rastra) dan bantuan pangan non-tunai (BPNT).

Rahardjo, M.D. 1993. Politik Pangan dan Industri Pangan di Indonesia. Prisma No. 5, Th XXII. hlm. 13-24. LP3ES. Jakarta. 
Setiawan, A. W. (2015). Pengaruh pertumbuhan ekonomi, pendapatan asli daerah, dana alokasi umum, dana alokasi khusus dan dana bagi hasil terhadap pengalokasian anggaran belanja modal di Kabupaten/Kota di Yogyakarta periode tahun 2007-2013 (Doctoral dissertation, Universitas Muhammadiyah Surakarta).

Sinaga, R. J. R., Lubis, S. N., \& Darus, M. B. (2013). Kajian faktor-faktor sosial ekonomi masyarakat terhadap ketahanan pangan rumah tangga di Medan. Journal on Social Economic of Agriculture and Agribusiness, 2(5).

Suryana, A. (2008). Menelisik ketahanan pangan, kebijakan pangan, dan swasembada beras. Pengembangan Inovasi Pertanian, 1(1), 1-16.

Suryana A. 2013. Undang-undang nomor 18 tahun 2012 tentang Pangan. Disampaikan dalam Kuliah Umum Mahasiswa Sarjana dan Pascasarjana, Jurusan Agribisnis, Institut Pertanian Bogor; 2013 Des 14; Bogor, Indonesia.

Susilowati, H., \& Purnastuti, L. (2014). Faktor-faktor yang mempengaruhi ketahanan pangan rumah tangga miskin di kecamatan srandakan bantul. Universitas Negeri Yogyakarta. Tidak dipublikasikan.

Undang-Undang Republik Indonesia Nomor 41 tahun 2009 tentang Perlindungan Lahan Pertanian Pangan Berkelanjutan. http://www.deptan.go.id/bdd/admin/uu/UU.20No.20.4120Tahun20.2009.20tent ang.20PLPPB.pdf. diakses 16 Maret 2011.

Wastutiningsih, S. P., Untari, D., \& Agus, S. (2011). R., dan Tri Dyah. 2012. Kebijakan Pengembangan PanganLokal melalui Penyuluhan Pertanian Menuju Kedaulatan pangan di Kabupaten Bantul. Jurnal Ilmu Pertanian 16 (2), 69-75.

Wulandari, W., \& Purnomo, E. P. (2019). Collaborative Government dalam Mewujudkan Inovasi Pelayanan. JIP (Jurnal Ilmu Pemerintahan): Kajian Ilmu Pemerintahan dan Politik Daerah, 4(1), 13-28. 